This is the accepted version of the article published in Journal of Professions and Organizations, 2019, 6(3). You can access the article on the Oxford University Press website: https://academic.oup.com/jpo/advance-article-

abstract/doi/10.1093/jpo/joz011/5614328?redirectedFrom=fulltext

Fragmented fields: professionalisms and work settings in Italian management
consultancy.

\title{
Abstract
}

Management consultancy has long been a contested terrain in the sociology of the professions. Although the professionalism of management consultants has always been emphasised by practitioners themselves, the lack of a strong community of peers has been an impediment to their professionalisation. In this article, I argue that professionalism is not the outcome of a process of regulation and institutionalization, but that it has to be conceived a discourse comprising norms, worldviews and values that define what is appropriate for an individual to be considered a competent and recognised member of this community. Given the diversity characterising the field, there are multiple discourses surrounding professionalism of management consultants, and these discourses are shaped by work settings. Work settings are a combination of the type of organization (professional partnership or professional service firm) and the employment status (employee or self-employed). Drawing on the empirical evidence from various work settings (professional service firms, professional partnership and selfemployment), I investigate four clusters of practitioners identified in 55 biographical and semistructured interviews conducted with management consultants in Italy. Four types of professionalism emerge from the clusters. Organizing professionalism is the sole professionalism which appears in all work settings. Other discourses (corporate, commercialised and hybrid professionalism) are context-dependent and more likely to be found in specific work settings. 


\section{Fragmented fields: professionalisms and work settings in Italian management consultancy.}

The expansion of 'new' management occupations calls for a theoretical reformulation of the professionalism concept. Historically, managerialism and professionalism have always been seen as separate logics, but recent empirical evidence shows that specific forms of professionalism are developing from a fruitful hybridization (Noordegraaf, 2007 and 2015; Butler and Collins, 2016; Heusinkveld et al, 2018). Management consultancy is at the heart of this change, due to its ambiguous role between management and the professions (Butler and Collins, 2016; Collins and Butler, 2019).

However, management consultancy has commonly been considered a lesser professional activity than traditional professions (Reed, 1996; Kieser and Groß, 2006; Fincham, 2006; Clark and Kipping, 2012). But, is professionalism a quantifiable phenomenon? The impression of 'lesser' professionalism can be imputed to the application of models of professionalization derived from collegial professions, such as medicine or law (Butler and Collins, 2016; Collins and Butler, 2019). Such analyses have been criticised for their lack of theoretical dynamism and an inability to account for the development of 'new' management occupations (Watson, 2002; Adamson et al, 2015; Heusinkveld et al, 2018). In simple terms, 'new' management occupation scholars argue that collegial models of professionalization are not suitable for understanding the nature of management consultancy (Heusinkveld et al, 2018). Professions like management consulting have a knowledge/skill base which is organization-specific; they are forced to rely on a task repertoire that is fragmented, diverse and contextual-dependent (Reed, 1996).

Following this argument, I assume that professionalism is neither the outcome of a process of regulation nor a collegial stance, but relates to "how practitioners explain their work (Cohen et al, 2005: 776)", aligning with the discursive tradition in the study of professions (Fournier, 1999; Evetts, 2013; Olakivi and Niska, 2016). Professionalism is a discourse comprising norms, worldviews and values that define what is appropriate in a certain occupational group in order for an individual to be considered a competent and recognised member of this community. According to Watson (2002), Kitay and Wright (2007) and Olakivi and Niska (2016), discourses are sets of interconnected concepts, expressions and statements that give sense to professional and organizational phenomena. Discourses are meaning-making resources (Alvesson and Johansson, 2002; Kipping, 2011; Olakivi and Niska, 2016) that shape professional socialization (Anteby et al, 2016), and they are deeply embedded in socioeconomic, political, cultural, and organizational contexts (Cohen et al., 2005; Suddaby et al, 2009). Choosing this definition of professionalism implies looking at "the ways in which a combination of occupational values and broader discursive issues act within organizational fields to shape day-to-day working relationships and broader obligations (Collins and Butler, 2019: 4). A discursive concept of professionalism can be usefully applied to all those occupations that do not fit the collegial model of professionalization, in order to investigate to what extent and how their practitioners lay claim to and enact professionalism. But it is also very effective to observe their political stance: members of occupational groups use discourses as rhetorical devices and ideological resources to further their interest and to give legitimacy to their claims over material and symbolic resources in society (Watson, 2002; Collins and Butler, 2019). In Alvesson and Johansson (2002: 229), professionalism is "a resource on which management consultants can draw selectively upon in their claims for authority, status and credibility". 
A second point to be made is that relatively little consideration has been given to the extent to which different work settings impact on professionalism. In this paper, work setting refers to the combination of type of organization in which the professionals perform their work and their employment status (see Table A3). I argue that the diversity of work settings within which management consultancy is performed and the lack of a unique and strong actor capable of imposing a dominant discourse on "how to be professional", fragment professionalism in this field. As noted by Kitay and Wright (2007) and Kipping (2011), heterogeneity and conflicting identities are more likely in professions like management consultancy, which is characterised by an inability to establish a traditional professionalization (Collins and Butler, 2019), by a broad range of specialties and organizations (Kitay and Wright, 2007), and by the role played by corporations in undermining attempts to professionalization (Muzio et al, 2011). In fact, given the lack of a strong professional association that would be able to define what is professional and what is not in the field, the importance of employment status and organizations are greater than for collegial professions, regarding the definition of professionalism. I argue that fragmentation in professionalism experienced in management consultancy might be better explained by the multiplicity of work settings than by weak professional commitment.

In this paper I demonstrate that the lack of a strong community of peers agreeing on a dominant professionalism that is accepted and endorsed by practitioners rather it changes the sources of professionalism, meaning that work settings become the locus for generating professionalism. Any organization might constitute a professional community to substitute for the lack of a dominant actor; the employment status mediates the relationship between practitioner and organizations. This results in a multiplicity of professionalisms, as varied as the work settings in which consultancy is provided. This multiplicity is open to hybridity in professionalism, not to its absence (Butler and Collins, 2016). Hence, if scholars reframe professionalism more dynamically, discourses about 'being professional' can be plural and equally legitimate.

Starting from these considerations, I argue that the nature, extent and variety of professionalism in management consultancy might remain largely unknown if the diversity of the management consultancy work setting is not considered. The concept of work setting is operationalized as the type of organization (professional partnerships PPs vs. professional service firms PSFs ${ }^{1}$ ) and employment status (dependent vs. self-employed workers ${ }^{2}$ ). Thus, I investigate discourses on the professionalism of management consultants as they become embedded in diverse work settings. To explore these dynamics, the following research questions are posed: what are the main discourses through which management consultants claim to be professional? Are discourses on professionalism influenced by the type of organization and/or practitioners' employment status?

Although several authors have stressed the intrinsic limitation of conceiving of professionalism as monolithic and unitary (Hanlon, 1996; Cohen et al., 2005; Faulconbridge and Muzio, 2007; Noordegraaf et al., 2014; Butler and Collins, 2016), empirical evidence on the role of work settings in determining multiple professionalisms in management consulting has been limited, as research has focused largely on employees in professional service firms (for example Grey,

\footnotetext{
${ }^{1}$ In the context of this paper, I assume corporations to be represented by the model of professional service firms, although several scholars have proposed to further distinguishing them by using the model of Managed Professional Business (MPB) or the Reconstructed Professional Firm (RPF). These concepts mostly differ from PSF in terms of corporate governance (Greenwood and Empson, 2003), an aspect which has not been investigated in the present project - although fiercely debated in the literature (Brock, 2006; Ackroyd and Muzio, 2007; Faulconbridge and Muzio, 2007; Scott, 2008; Muzio et al, 2011; Clark and Kipping, 2012).

${ }^{2}$ With the term employment status, I refer to the contract that the practitioners have: employee or self-employed professional. Situations may be the more varied in my sample, as management consultants might be employees of a consulting company or collaborating with freelance under exclusive license. They might be partners in a professional partnership, but at the same time they are their freelance supplier. Table A3 in the appendix clarifies the point.
} 
1998; Kipping, 2011; Muzio et al., 2011; Fincham, 2012; Heusinkveld et al, 2018). This has resulted in a lack of evidence from other work settings, such as small and medium-sized companies or self-employment (for notable exceptions, see Kitay and Wright, 2007; Furusten, 2013; Maestripieri, 2016; Maestripieri and Cucca, 2018; Cross and Swart, 2018).

This article aims to fill this gap in the current debate, drawing on data collected in 55 biographical and semi-structured interviews with management consultants in Italy and working in professional service firms, in professional partnership and self-employed. The resulting typology presents four different clusters of 'being professional' which map professionalism in Italian management consultancy: 'yuppie', the 'unwilling' consultant, the 'self'-employed, the 'professional' consultant. These clusters emerged inductively by applying positioning (Davies and Harré, 1990; Bamberg, 1997; Kohler Riessman, 2008) and biographical analysis techniques (Bichi, 2002; Olagnero and Saraceno, 1993). The results were interpreted using the analytical framework of career transitions, focusing on three distinct elements: the type of organization in which management consultants provide their consultancy (Vinkenburg and Weber, 2012), the transition between multiple employment statuses (McLean et al., 2012), and dominant career orientation (Rodrigues et al., 2013).

The paper starts with the review of relevant literature, particularly focusing on professionalism diversity as it emerged in previous studies. Following the methods section where I describe the the biographical and narrative approach used in the analysis, I discuss my results. I conclude the article by discussing my findings in the context of existing literature pointing out the role of work setting in determining which type of professionalism each cluster claims.

\section{Multiple professionalisms and variety of work settings in management consultancy}

The literature is currently assessing the declining centrality of the 'collegial' model of professionalism, theorised as a regulatory institution defined by peer control (Freidson 2001). New theoretical perspectives have progressively examined the penetration of organisational logics in professionalism (Faulconbridge and Muzio 2007) and organizations are now conceived as the primary location of and vehicle for professional action (Muzio et al, 2013). The resulting hybridisation (Noordegraaf 2007; 2015) has led to a rise in new concepts like commercialised professionalism (Hanlon 1996; 1998) or corporate professionalism (Muzio et al, 2011), stressing the increasing role of organizations as a source of professional regulation. The reinterpretation of professionalism by the organisations in which professionals provide their services weakens the heuristic capacity of collegial professionalism as an analytical tool (Watson, 2002). Authors contrast highly-regulated collegial professions with fragmented forms of professionalism, characterising "weakly regulated fields with little agreement on methods and norms (Noordegraaf et al, 2014: 22)" as 'new' management occupations (Heusinkveld et al, 2018).

Fragmentation is found in fields with heterogenous work practices and diversity in the organizational context in which the professional practice is provided. Management consultancy is a field characterised by heterogenous work practices, weak regulation and high differentiation in work settings (Kitay and Wright, 2007; Kipping, 2011; Collins and Butler, 2019). In the past, authors have discussed the source of this heterogeneity (see Alvesson and Johansson, 2002 for a review). Identified sources were usually the nature of consultancy work, the types of client, and the management consultants' position within the hierarchy of consultancy companies. The various typologies have focused on how the activity of consultancy was practised. But, seldom is heterogeneity a concept related to employment status or to the type of organizations within which they practice. 
In fact, the variety of professionalism in relation to the organizational fields has been already acknowledged by previous studies, when focusing on the attempts of large professional service firms (PSF) to institutionalize their own models of professionalism (Muzio et al, 2013). For instance, Kipping (2011) reconstructed the history of management consultancy by considering discourses on professionalism as a resource mobilised by consulting companies from the early $21^{\text {st }}$ century up to the present. He identifies three main waves in the evolution of management consultancy firms: "scientific management" (1900-1970), in which professionalism was derived from a close association with existing and similar professions like engineering; "strategy and structure" (1940-1990), in which professionalism emulates the legal profession and "information and communication" (1960 - today), in which professionalism has become a purely linguistic notion, arguing in terms of authority, status and credibility (Kipping, 2011). However, the distinction drawn between different perceptions of professionalism is limited by a focus on PSFs in the Anglo-Saxon market, with heterogeneity emerging only when confronting this same group and its evolving specialties over time.

Analysing the longitudinal development of management consultants' professional association in the UK, Butler and Collins (2016) argue that consultants have pursued various modes of professionalism, located between collegial and corporate professionalism. Instead of focusing on their weak or incomplete process of professionalization, they focus on the conditions that make impossible for management consultants associations to pursue a collegial professionalization, namely the unwillingness of large firms to cede control on cognitive and normative mechanism to the institute. They argue that a hybrid professionalism emerged from this situation; professionalism is located within organizational practices (Butler and Collins, 2016).

But, since much of the research focuses on PSFs (e.g. Alvesson, 2006; Faulconbridge and Muzio et al., 2011; Sturdy, 2011; Kipping and Clark, 2012), they seem to be treated as the sole locus in which management consultants operate, underestimating other work settings (Cross and Swart, 2018). However, there are several notable exceptions in the literature that do take into account different work settings and their impact on professionalism, showing how they are an important element in defining the professionalism of management consultancy. Furusten (2013) focused on small and medium-sized companies in the context of management consultancy. His results show that the role of organizations in defining professionalism is weaker than in larger organizations, while market logic is more important. A recent study by Maestripieri (2016) on those practising as independent professionals stresses the role of personal networks, on-the-job training, and market success in defining management consultants' professionalism, instead of intermediate bodies as professional associations. Cross and Swart's study (2018) showed that rather than seeking the institutionalization of their professional position, freelance consultants in UK take advantage of ambiguity in professional identity. Credibility and acknowledgement do not stem from a strong identification with a profession, but rather from their marketability. Hence, the three studies cited above emphasise that the commercial logic dominates the professional discourse in management consultancy, when other work setting than PSFs are taken in account.

Although not rooted in the mainstream debate on professionalism, Kitay and Wright's (2007) study is relevant, being one of only a few to take varying employment status into account in studying management consultancy. The authors reconstruct what they call the 'rhetorics of management consultants', as an outcome of the discursive process involving fitting meaning into a work setting. They identified five meaningful discourses associated with management consultancy; observing that variation between them arises from authors' specific empirical approaches, which are not limited to gathering data from those employed in large corporations. Their participants ranged from PSF employees to self-employed professionals. The rhetoric of 
the "Professional" was recognised as the closest to ideal-typical professionalism, and is the most diffuse among all types of respondents, with almost half recognising it. Other rhetorics such as "Prophet", "Partner", "Business Person" and "Service Worker" are context-dependent, and consultants use them depending on the specific structure and/or scale of the consultancy company or its specialty (business strategy, information technology, human resources and operational efficiency) (Kitay and Wright, 2007).

In line with Kitay and Wright (2007), Sudabby et al's (2009) study on accountants shows that work setting does matter when defining the values associated with a profession. Their analysis demonstrates the possible co-presence of values inspired by the logic of ideal-typical professionalism and managerialism in professional partnerships. This study shows that working in a PP does not imply higher support for ideal-typical professionalism's values. By contrast, among those who work in Professional partnership, there is strong commitment to the organization itself and a growing importance of commercial logics, with no apparent conflict between commitment to professions and commitment to organization. They also argue that the fragmentation of values is best understood by looking at the work settings. Those who work in PSF clearly distinguish themselves from the accountants of other firms regarding their attitudes to professional institutions and ideology, showing lower levels of affiliation to the profession. Notably, Suddaby's study does not take into account self-employed professionals.

The review of the previous study shows that work settings are increasingly important in shaping attitudes, norms, and opinions among professionals and that fragmentation is likely to emerge from work-setting diversity.

\section{Research questions and methodology}

The study investigates the role that the type of organization (professional partnership or professional service firm) and the employment status (employee or self-employed) play in defining management consultants' professionalism, extending the analysis to professionals working in small companies and freelance. It uses research design inspired by Kitay and Wright (2007), based on analytic induction (Morse and Mitcham, 2002). I went to the field with the aim of exploring professionalism, conceptualised as discourses, prescriptions, norms and practices associated with performing management consultancy in a "professional way". The outcome of the study, shown in Table 2, is an inductive-based typology that categorises the discourses that emerged in the interviews.

The analysis is based on data collected from 55 biographical and semi-structured interviews. Interviews were conducted with a sample of management consultants in Italy during 2009/2010 as part of the author's $\mathrm{PhD}$ thesis (Maestripieri, 2013). Italy is of particular interest in the field of MC research, because the labour structure of Italian management consultancy is unique in a comparative perspective, due to its simultaneous fragmentation and concentration (FEACO, 2018). Approximately $85 \%$ of all businesses $(16,000$ organizations) have fewer than three employees, while just 35 firms with over 50 employees control more than $50 \%$ of the market (Assoconsult, 2015). Previous estimates, based on the Italian labour force survey (Maestripieri, 2013), suggest the total population of Italian management consultants is approximately 45,000 workers (including freelancers and employees), of which the author estimates that less than 3 in 10 consultants are employed by PSFs (own elaboration on Assoconsult, 2015). The relatively large role played by microbusinesses, i.e. controlling approximately one quarter of the market, arises from the fact that the structure of the Italian manufacturing system is still based on a primarily family-owned model of micro-companies. This means that the Italian market is characterised by the small dimensions of buyers (Colli, 2010), which has consequently impeded 
the growth of consultancy firms and increased the diversity of the field (see the data presented in Table 1 in appendix).

The Italian case thus represents an ideal situation for researching the diversity characterising management consulting market. The sampling design aimed at representing the organizational variety of the Italian consultancy market using a purposive approach (Creswell, 2002). The 55 interviewees are distributed as follows: freelance consultants ( 25 interviewees), practitioners in small to medium-sized enterprises (20 interviewees) and consultants in professional service firms with over 50 employees (10 interviewees) ${ }^{3}$. Sampling terminated when I felt that the critical point of saturation had been reached (Saunders et al, 2018), so that additional interviews would not have added new information. Selecting participants for the study was not straightforward. Management consultancy in Italy is an unregulated profession, implying that there are no legal obligations for management consultants to participate in a professional association, to observe professional standards, or to obtain any certification or specific degree in order to provide professional services. Moreover, the professional associations do not help to delineate who warrants professional status. There are two associations, the APCO for selfemployed people and microenterprises, and ASSOCONSULT representing larger companies. However, neither represents the majority of Italian practitioners (Crucini, 1999; Author, 2013).

Defining boundaries in management consultancy is not easy either (Kitay and Wright, 2007); professionals with very different educational backgrounds and specialties can claim to be consultants. The selection criterion for identifying respondents was thus very pragmatic; professionals were included in the study if they presented themselves as management consultants, in line with Kitay and Wright (2007). This assumption yielded a sample that varies in terms of specialties and employment status, ranging from self-employed psychologists specialising in organizational climate to corporate strategy consultants in IT services. However, the majority of the interviewees have economic or engineering backgrounds (two interviewees have only a secondary school certificate as their highest qualification, while the remainder have completed tertiary level education with varying specialisations). The variation in sector and background is accounted for in the analysis that follows (see appendix, Table A2).

I selected the interviewees by employing a number of sampling strategies. Three SMEs were involved in the research project in the first phase, and their employees/collaborators were all included in the analysis (Group 1). Freelance professionals and owners of small firms (Group 2) were selected from a list provided by the professional association APCO, and via snowball sampling conducted after the initial interviews. The final group (Group 3), comprised corporate professionals who had been identified by interviewees from groups 1 and 2 using snowball sampling. A semi-structured interview template was developed from the analysis of group 1's biographical interviews, conducted prior to the group 2 and group 3 interviews. The group 2 semi-structured interviews also formed part of a concomitant project on professional selfemployment (Ranci, 2012). Demographic characteristics of the sample are presented in Table A2.

The research design was sequential, combining two qualitative techniques of data collection. The initial stage entailed biographical interviews to map the concepts associated with management consultancy and the events that lead the person to become a consultant. The biographical interviews (Bichi, 2002) afforded the interviewees in group 1 considerable freedom when responding, as the participants were asked only one starting question: "Tell me about your job, starting wherever you like". Prompts (Leech, 2002) then investigated career progression aims and aspirations, discourses associated with professionalism, the ways in

\footnotetext{
${ }^{3}$ For a complete overview of work settings of the interviewees, see Table A3 in the appendix. For further reference to work settings, the extracts of the interviews presented in the results are identified using the groups presented in Table A3.
} 
which professional activities were performed, and the role of the type of organization. The second stage involved semi-structured interviews (group 2 and 3) to test the hypothesis based on the empirical evidence from the first set of interviews concerning the roles of organizations and employment status, as experienced by practitioners in different work settings. The structure and content of the semi-structured interviews was the same for all interviewees (Bichi, 2002); they started with a reconstruction of the person's career and its main events, and focused mainly on investigating the dimensions the interviewees associated with professionalism. Biographical insights were fundamental to reconstructing the relevant transitions between work settings that informed the typology of Table 2 and Figure 1.

The interviews were transcribed in full for the biographical ones (group 1), and transcribed using a predisposed template in the case of the semi-structured interviews (groups 2 and 3). The template reported the responses to questions from the semi-structured interviews, providing a summary by the author to highlight the content of interviewee answers, and including long quotations from interviewee. All interviews were transcribed and analysed by myself. Consistent with previous studies based on a discursive approach to professionalism (e.g. Cohen, 2005; Carollo and Solari, 2019), coding was intended to highlight beliefs, values, prescriptions, and all the arguments used by interviewees to claim their professional status, that I considered associated with professionalism.

The resulting texts were analysed using Atlas-Ti version 6, and clusters were developed inductively to group each participant on the basis of the similarity of their biographies. To develop the clusters, an analytical framework based on career transitions was applied to biographies through two techniques: positioning (Davies and Harré, 1990; Bamberg, 1997) and biographical trajectories (Olagnero and Saraceno, 1993). The first technique focuses on the set of references a person uses during an interview, and the second on the identification, emergence, and comprehension of key transitions and critical turning points in their narrative. Using positioning, the empirical data was organized according to the career orientations that emerged for each interviewee (Rodrigues et al., 2013). These were identified by establishing the principal figurative stance to which the interviewees benchmarked their career. The two key positions considered were manager and professional, which were assumed to represent the individual's career goal. Using biographical trajectories, the key events and transitions in the management consultants' careers regarding work (for example hiring, layoffs, and selfemployment activities), education (degrees or special training courses completed), and historical contexts (for example the financial crisis) were identified. The outcomes of this analysis were two emerging poles: remaining in consultancy, whereby an individual seeks to pursue a career as a consultant in the medium-long term, and moving from consultancy, whereby being a management consultant is regarded as a transitory situation. Therefore, the four clusters are based on a combination of the two dimensions: orientation (manager/professional) and trajectory (remain in/move from consultancy) (Table 1) ${ }^{4}$. After the interviewees had been divided according to these two dimensions, responses detailing what it meant to them to be professional among the various clusters, were analysed (Table 1).

For the purposes of this study, a 'career' is defined as an unfolding sequence of macro role transitions, involving movements between organizations, employment statuses, or professional roles held by workers along their biographies (Arthur et al., 2005; Ibarra and Burbulescu, 2010; Vinkenburg and Weber, 2012). A career has three important dimensions: first, it develops over time; second, it has a direction of progress, either upward, lateral, or downward; third, it occurs in specific locations, identified in this case by the organizations in which the management

\footnotetext{
${ }^{4}$ Two of the interviewees could not be categorised: the two women were employed in a professional partnership in junior roles as self-employed collaborators with limited experience in the role, and showed no intention of pursuing consulting in the future. They were economically dependent on a sole buyer, and with a limited involvement in commercial activities.
} 
consultants work (Vinkenburg and Weber, 2012). The analytical framework of career transitions encompasses several dimensions that are fundamental to how people present their professional discourse and its relationship to work settings. The resultant analytical outcome has a biographical nature, based on a sequence of transitions and roles over time. It is also contextual, because career orientations are defined by "relatively stable career preferences shaped by the interplay between individual identity, family and social background, work experiences and labour market conditions" (Rodrigues et al., 2013: 150). In the results section, all these elements are analysed for each of the four clusters mentioned above, to show emerging correlations within each cluster's professionalism. The results are presented graphically in Figure 1.

The typology of professionalisms emerged inductively from the analysis of interviews: the analysis aimed to link the discourses of each cluster in table 1 with previous theoretical interpretations of professionalism. Discourses revealed consistencies and similarities within each cluster and work setting (type of organization and employment status) were the main explicative dimensions that accounted for differences between professionalisms. The outcome of the analysis is presented in Table 2.

\section{The findings}

This section presents the four clusters of management consultants identified during the analysis (Table 1), and categorises their various ideas about 'being professional' in the type of organization within which they are active, using an analytical framework focusing on transitions between work settings and career orientation (see Figure 1). The four clusters form a typology of professionalisms (see Table 2), embedded in different work settings (Table A3). The interviewees are categorised according to their own narrative and biographical accounts of their careers as management consultants, as explained in the previous section.

Table 1 - The matrix of management consultancy clusters

\begin{tabular}{|l|c|c|}
\cline { 2 - 3 } \multicolumn{1}{c|}{} & REMAINING in consultancy & MOVING from consultancy \\
\hline $\begin{array}{l}\text { Positioning as } \\
\text { PROFESSIONALS }\end{array}$ & The 'professional' consultant & The 'self'-employed \\
\hline $\begin{array}{l}\text { Positioning as } \\
\text { MANAGERS }\end{array}$ & The 'unwilling' consultant & The 'yuppie' \\
\hline
\end{tabular}

\section{Management consultants as Managers: the 'Yuppie' and the 'Unwilling'}

The narratives of the first two clusters are positioned on management. For the management consultants belonging to these two groups (the 'yuppie' and the 'unwilling' consultant), being a consultant marks a discontinuity within a career in which attaining a managerial position is the final goal. These two groups distinguish themselves in terms of how they are positioned relative to managers. In the first case, a postalgic attitude (Ybema, 2004) is evident, longing for a better future in which the interviewee would assume a managerial position, thereby justifying current undesirable working conditions and limited autonomy (Stenger, 2017). In the second, a nostalgic longing for 'bygone days' characterises consultants whose careers as managers have been unwillingly interrupted (Ybema, 2004). 


\section{'Yuppie'}

"In general, the consultant is in a fast lane, in the sense that you have the chance at 25 years old, newly graduated, to work with people... with professionals [...] Then, as a consequence of the awareness of being in this fast lane, you necessarily become more ambitious, because you work twice as hard as the others and then, as a consequence, you tell yourself "come on, if I work twice as hard as the others I can build a career in half the time"....and this makes you very ambitious»

[Corrado, 31, SME employee]

'Yuppie' is an acronym of 'Young Urban Professional', which became popular in the 1980s to identify young men and women aged between $25-35$ who pursued self-realisation by accessing financial and managerial elites. This term ideally represents the first cluster of interviewees, as they are "aggressive, competitive, hardworking, and youthful" (Grey, 1998: 580). In the current meritocratic system, people acquire prestige and status by competing with each other (Gill, 2015); employment in a highly selective and elitist consultancy corporation is an effective strategy to obtain high social and economic rewards without strong professional or organizational affiliation (Anteby et al, 2016). The 12 interviewees grouped in this cluster (three of whom are female) are educated at top-level universities and MBA schools and hold managerial degrees (economics or process engineering). They are also the youngest (29 years old, on average) (see table A1 in appendix). Ambitions for a managerial career drive their engagement in management consultancy.

According to Maister, "people do not join professional firms for jobs, but for careers" (1993, cited in: Alvehus and Spicer, 2012: 502). Correspondingly, the management consultants within this cluster are focused on transition, generally viewing their consultancy activities as a temporary and instrumental stage, before attaining an executive position, for example becoming partners in a professional service firm, or managers in a 'normal' enterprise. Taking on a consultancy role in large firms is viewed as a way to move along a career path more rapidly than would be possible in other contexts. They estimate approximately five years to secure a managerial position, compared to $10-15$ years pursuing an in-house career in a normal enterprise.

"In practice, I wanted to get as much... experience as possible in in order to be autonomous in the future management of a company and add value, I therefore decided, so to speak, to prostitute myself with highest bidder in terms of experience, as long as my experience curve remains vertical, and at the moment it is clear that I will change [employer]»

[Tiziano, 25, PSF employee]

Being a corporate consultant is considered prestigious; only the very best students have the opportunity to access these jobs, and the organizations themselves frequently and actively recruit top graduates from elite universities (Kieser and Groß, 2006; Rivera, 2012). The professionalism of this group is profoundly informed by a corporate identity premised on elitism (Alvesson, 2006; Gill, 2015). The elitist discourse (Alvesson, 2006; Gill, 2015) is sustained by the stringent selection processes at each career step (with higher requirements in PSFs, and lower in medium-sized firms), which are based on an 'up or out' strategy. Career progression is not optional, rather, it is a requirement for 'staying in the game' (Morris and Pinnington, 1998; Kumra and Vinnicombe, 2008; Alvehus and Spicer, 2012; Stenger, 2017).

Professionalism is an exercise in conformism; in order to go up, they conform to the preferred behavioural standards of the corporation; usually being hardworking, reliable, and willing to defer to the hierarchy (Grey, 1998; Stenger, 2017). They also need to appear professional in 
dress, language use, and even in how they have fun, as an elite professional is expected to do (Grey, 1998; Alvehus and Spicer, 2012; Rivera, 2012; Costas et al., 2016).

For this cluster of management consultants, the company is the locus of their professionalism (Kipping, 2011; Muzio et al., 2011; Fincham, 2012). Being professional entails meeting the requirement of quantifiable productivity parameters in order to climb the internal hierarchy of the firm, rather than an opportunity for sharing competencies and skills with a community of peers (Alvehus and Spicer, 2012). The company itself uses professionalism as a way to control its employees, for shaping their consultancy style and ensuring their loyalty to the company (Kipping, 2011).

"You enter the *company* and are immediately strongly settled, you are framed in a model of work that is theirs, which is standardised and evolved over time, and it works as well»

[Lamberto, 34, SME employee]

Interestingly, none of the PSF partners were in this cluster, suggesting that even in a PFS, becoming a partner requires a stronger attachment to the consultancy profession. Not all the respondents clustered within this type are PSF employees; some are employed in medium-sized companies. None of them is self-employed nor a collaborator/partner in a small professional partnership. Furthermore, none of the interviewees in this group has ever aligned with a professional association.

\section{The 'unwilling' consultant}

"I decided to become a consultant [...] because I understood that there was no future... I didn't see any future, not only in terms of development, but mostly not too much chance of... of keeping my job at the end. This has happened to me, but I think it is an experience that was very common during the '80s and '90s. In short, it has happened to many workers, really MANY [...]. There are a lot of companies that don't mean anything to you, but in the past they were training companies for information systems, my company *** reached 4000-5000 employees by the end of the '80s, yes it did, and now... in just 15 years, 10 years, there is nothing left'”

[Mario, 53, Partner in a PPs]

The 'unwilling' consultant cluster of management consultants is composed of consultants who had already reached executive positions in a non-consultancy firm, but for various reasons (company failure or restructuring, or due to being made redundant), they had been forced to relinquish their managerial roles. They represent the 'collateral damage' arising from the reorganization of companies and services, as part of a general trend towards de-industrialisation in advanced capitalist societies. Only five interviewees are grouped into this cluster, but their biographies are consistent enough to form a distinct group. They are all middle-aged males, with variable educational profiles (two have only secondary school diplomas) and variable occupational status. One is a senior consultant in a SME, one is a freelance consultant, three are collaborators or partners in small professional partnerships (see Table A1 in appendix).

Since dismissal from their previous managerial posts, they have pursued a career in consultancy, because it is the easiest way to exploit their competencies. However, they perceive their current position as beneath their previous roles as managers. These 'unwilling' consultants have had to navigate the social trauma of losing their jobs, an event that interrupted their planned career progress (Dubar, 1998; Ybema, 2004; Mendehall et al., 2008; Costas and Grey, 2014). However, their narratives of failure and nostalgia are softened by the fact that they were 
able to reinvent themselves as consultants, although with varying degrees of success. Nevertheless, because their career patterns have diverged from the traditional upward model, their roles as management consultants are referred to in negative terms, suggesting a view of success based on rising income or hierarchical advancements (Vinkenburg and Weber, 2012).

"You have been an employee for 20 years, you have been under the brand of a big company, isn't it? You had relationships with clients, but, hey, you don't have your own relationships, you don't have a market... let's do the freelance, yes, and then how do you find your clients? Who are you? Which referees can you name? Nobody»

[Mario, 53, Partner in a PPs]

"I would divide the consulting world into two big sectors, that is, one of professional consultants and one of the managers, let's call them like that. In other words, those who at a certain point in their career offer themselves as consultants. But the main difference is that the professional consultant has actually developed an approach and technical skills, while the manager just replicates his own experience and just transfers it to clients»

[Pietro, 48, freelance in exclusive licensing for a SME company]

The professionalism of this cluster is bolstered by being part of two worlds, and the concept of hybridity describes their ambivalent understanding of what it means to be professional (Noordegraaf, 2007). They represent a partial combination of the two logics of managerialism and professionalism; a hybrid professionalism proceeding from the amalgamation of normally separated elements that are central and moderately persistent, but still not entirely cohesive, imparting a feeling of 'unease' (Noordegraaf, 2015: 188). Professional associations were used instrumentally at the beginning of their self-employment as places to find peers, potential partners, assignments and collaboration opportunities, but mostly just to avoid feeling alone.

\section{Management consultants as Professionals: the 'self'-employed and the 'professional consultant'}

These two clusters are distinct from the previous two, in that the main positioning of interviewee narratives is the professional. However, in the everyday language of Italian management consultants, 'professional' means something slightly different to what is theorised in sociological debate. In the words of the interviewees, being a professional means having complete autonomy to self-manage and complete one's own tasks, a belief based on emphasising expertise and market success (Maestripieri, 2016). Thus, the term 'professional' is ambivalent, indicating someone who is freelance and selling services successfully to the market, while also being synonymous with recognised competence in an expert occupation.

The prevailing meaning of professional (expert or freelance) distinguishes between the two clusters in this section. In the case of the 'professional consultant', there is a clear tendency to assume a clear-cut professional project centred on a set of specialist consulting services. By contrast, for the 'self'-employed cluster, workers are willing to be autonomous, with the primary goal of remaining in the market, regardless of the scope of services offered.

\section{The 'self'-employed}

"In the condition of someone who works like me [freelance], a consultant is also an entrepreneur and you have no certainty. Because I am clearly dependent on the 
market and the market is not a fixed variable, it is always changing. Then, if you are able to be in there, you are also able to give yourself stability»

[Raffaele, 50, freelance]

Management consultants in this cluster present themselves as self-employed workers, a condition that enables them to exercise consulting services with complete autonomy and freedom. Two main pathways to self-employment emerged from the interviews. One group entered the labour market as self-employed workers, because they have always been attracted by freedom. For the other group, the decision to become self-employed was made after a period as an employee, and arose from choosing autonomy over wealth and security. The 10 interviewees grouped into this cluster are mainly stand-alone freelancers, with three being owners of their own small service companies. Only one offers specialised services, while the others are 'general' freelance workers (Cucca and Maestripieri, 2014), locally based and serving micro firms, offering consultancy among other services, such as training, education at universities or at advanced vocational training centres, and tax and business advice. All of these interviewees are middle-aged, and only two of the ten are women.

In this cluster, the content of the management consultants work is not relevant to defining what it means for them to be professional. The most important point is their occupational status "beyond" management consultancy, that is, being self-employed. These interviewees had decided to offer consultancy services after observing that consultants were attractive in the market. As such, their consulting activities are not easily distinguishable from the services of tax advisors, the most common external support staff for SMEs. Consultancy does not afford a strong anchor for their professional identity. They are what their clients need them to be (Cross and Swart, 2018).

«Being a freelance has never been a concern, I will work, I will earn, I will have job, never a concern. I always thought, do you have a network of people? Then, feed it. You have to prove yourself a person that people like, someone in whom they find utility and then people call you back»

[Alice, 55, freelance]

"If I thought of tax advisors, lawyers, notaries which are regulated professions, things are not so different. I have seen advisors who did terrible damages, in this case it is the market that has to be selective»

[Iacopo, 55, Partner in a PPs]

From the perspective of 'self'-employed interviewees, competencies have to be ratified by the market, not by institutions or organizations. They embody the principles of market fundamentalism in their everyday professional practice: consumers know it best, markets will determine what is right, collegial orders are attempts to collect monopoly rents, there is no need for a code of ethics (Leicht, 2016). In line with the notion of commercialised professionalism (Hanlon, 1998), consultants in this cluster feel professional, because the client is content with the service they provide and is willing to purchase their expertise. That is, competence is defined by market success and a professional is the person who is able to sell his/her own services on the market. Thus, for this group, membership of a professional association becomes just one of the various sources of distinction they can use as a strategic tool for competing with peers.

\section{The 'professional' consultant}


"Since consultancy is a profession, it has a series of experiential elements that are built up over time, in terms of relationships with people, of client management etc., which cannot be extemporised, and can be acquired only through experience»

[Pietro, 48, freelance in exclusive licensing for a SME company]

Differing from the previous three categories, the largest cluster of interviewees (26) are employed in various types of organizations, with differing employment status. The participants in this cluster share a strong passion for their jobs; providing consultancy services is something that satisfies their personal desires and career ambitions. All the interviewees in this cluster have a degree, and although there was a bias in the direction of management (16), several practitioners had come from unusual disciplines for a management consultant, including astronomy, chemistry, and philosophy. Women represent more than one third of this group, with junior and senior consultants equally distributed (see Table A2 in appendix). The two partners in PSFs are classified here.

Expertise is what drives their discourse on professionalism, and it is the feature they share with the purest ideal-typical forms of professionalism (Noordegraaf, 2007). They apply abstract knowledge to specific cases, but became experts through their everyday practice, stressing the role of organizations as the main locus of professional socialisation (Anteby et al, 2016).

«We do not have a structured and systematic assessment, we do not have a mark. What we do regularly is a meeting, it is called a technical meeting, in which we all gather, and present to our colleagues what we do [...] these assessments are periodic with our colleagues and we build together the lessons learnt»》

[Aldo, 44, SME employee]

Knowledge and skills are codified within their organizations, more so than in associations or in the context of university education. These practitioners learn how to behave and how to react appropriately by imitating their colleagues in everyday practice. For this reason, their professionalism cannot be defined as pure (Nooerdegraaf, 2007), as there is no institutionalised control of professional practices, because neither of the two Italian management consultancy associations has sufficient members or power to serve as the principal actor to define, develop and control professionalism. Even stand-alone professionals share the same approach to professionalism. In their case, the process of professional exchange occurs through collaborative networks, which are only partially populated by colleagues encountered in professional associations. Being included in networks of the usual collaborators at larger professional partnership is fundamental for updating and developing their knowledge (Maestripieri and Cucca, 2018).

"I have always followed this strategy. I had one or two main clients from which I earned real money, and then three to four, and even more buyers that supported me more with relationships, communication and learning. These latter projects are less remunerative, but I usually learn more, while the more remunerative projects usually have a lower rate of innovation. The risk I might incur is clear: if I only pursue less innovative projects, when they end, I might find myself out of the market, while having relationships with three to four larger consultancy firms avoids this risk, as I do special activities for them»

[Antonio, 61, freelance]

Distinct from the corporate professionalism of 'yuppies', this cluster uses its own agency to develop its own professionalism within the organization in which they work or with whom they collaborate. They do not exhibit a superficial conformism to a consultancy style similar to the first cluster: they embrace the professionalism of their organization, but only as a starting point 
for developing their own consulting style. Consequently, when their occupational conditions changed, or when they had migrated from one organization to another, they are not driven exclusively by a desire for upward career momentum (in terms of income or hierarchy). Their primary incentive is often to find new opportunities for collaboration and because they are attracted by interesting projects. The career path for these individuals might involve lateral movements, shifting between self-employment and dependent work in various type of organizations.

"When I was working in a chemical company, I resigned to do an MBA in Bologna [...] in which the majority of the courses were from *company* consultants. Then, I had an internship in a chemical company, but when I realised that they were looking for personnel in *company* I applied, because it was really... I was really passionate about the themes, with the way they presented their company to us and I said to myself 'let's try it' and the passion was born. Because it is really a matter of passion for those who do this job»

[Ada, 32, freelance in exclusive licensing for a SME company]

Interviewed consultants in this cluster display a strong emotional affiliation to the profession, despite changes in work settings and different work content. There are signs of the emergence of 'pure' professionalism among them, but it is not based on the involvement of formal recognition and the central role of a professional association. As either employees or freelance, the core of their professionalism is the content of their consultancy services, the projects they are able to work on, and the methodologies they develop in a continual desire to improve and fine-tune their own professional skills, which are shared with peers in personal networks or in their organizations.

\section{Discussion: Towards a typology of professionalisms}

Figure 1 summarised the evidence presented in the results section. The four clusters of Italian management consultants are placed in relation to work settings and orientations to map the configurations of management consulting professionalism. Work settings and career orientation give the coordinates to map professionalism in management consulting. Although professionalism is a powerful resource for all clusters of management consultants, the type of professionalism changes across clusters (Table 2).

Figure 1 - Orientations and work settings in the four clusters of Italian management consultancy. Arrows indicate transitions along work settings and orientations. 




The cluster 'professional consultant' ( 26 interviewees) is the only one present in all work settings and is characterised by a stable orientation to management consultancy along interviewee biographies, which is stronger than work-setting affiliation.

Professionalism in this cluster is an organizing professionalism (Noordegraaf, 2015), because professionals are socialised to management consultancy inside the organization (or the network) in which they are embedded. However, their professionalism extends beyond the conformist application of corporate norms which characterises 'yuppies'. It goes beyond this, because management consultants display agency through the manner in which they make their organization's professionalism their own personal way of interpreting the concept. They offer expert knowledge developed through experience, are committed to and passionate about their work, independently basing decisions on their own judgement (Kitay and Wright, 2007). Their identification with the profession is strong, revealed in a tendency to prefer the development of innovative consulting practices and the foundation of new partnerships when progressing along their career, which might proceed along different work settings. In fact, the same interviewee might have changed work setting along own biography.

The other three clusters instead show a concentration within a specific work setting. 'Unwilling' management consultants ( 5 interviewees) are mainly found in self-employment, as freelance practitioners or partners in small professional partnerships. They demonstrate a stable orientation towards management consulting as well, but it has not always been so. They have arrived in management consultancy as a second-best option, after the loss of a job in management, which still represents the main orientation of their narratives. Their identification with management consultancy is weak, as it is perceived as a fall-back position from management.

Professionalism in this cluster is a hybrid professionalism (Noordegraaf, 2007): managerial logic is juxtaposed with professional logic here, as the management consultants belonging to this cluster are ex-managers who have entered consulting as a fall-back role. Their professionalism is strongly influenced by their previous experience as managers, which results in the replication of previously learnt managerial practices. Professional practices are not clearly separated from managerial experience; hybridity between the two logics (professionalism and managerialism) is the natural consequence.

The remaining two clusters concentrate mainly in two work settings: 'yuppies' are employees in PSFs, and the 'self'-employed are freelance or (less frequently) work as partners in small professional partnerships. In both cases, their identification with management consulting is weak, temporary and mainly instrumental. Traditional professional affiliation is implicitly 
assumed to be life-long, but not in this case; it is an 'image' of professionalism used temporarily at the convenience of the interviewee (Kipping, 2011).

Professionalism among 'yuppies is corporate professionalism (Muzio et al., 2011): professional discourse is deeply embedded in practices, narratives, and routines that belong to the large PSF in which the management consultants operate as professionals, usually relying on models and activities organized at the corporate level. Their professionalism is strategic and one of convenience.

Professionalism among 'self'-employed is a commercialised professionalism (Hanlon, 1998): professionalism is a rhetorical argumentation based on commercial activity as a self-employed consultant, and is used to claim legitimacy as an expert in the market, without strong commitment to a specialised body of knowledge. As soon as the market demand changes, professionals in this cluster will adapt the services they offer accordingly.

Table 2 - A typology of MC professionalisms

\begin{tabular}{|l|c|c|c|c|}
\hline The 'yuppie' & Orientation & Direction & Professionalism & Work Setting \\
\hline The 'unwilling' & Professional & Persistence & $\begin{array}{c}\text { Corporate } \\
\text { professionalism }\end{array}$ & $\begin{array}{c}\text { Dependent work in } \\
\text { PFSs }\end{array}$ \\
\hline professionalism & $\begin{array}{c}\text { Self-employment } \\
\text { (freelance and } \\
\text { Professional } \\
\text { partnership) }\end{array}$ \\
\hline The 'professional' & Professional & Transition & $\begin{array}{c}\text { Organizing } \\
\text { professionalism }\end{array}$ & All \\
\hline
\end{tabular}

Reflecting on Table 2, there are three important issues stemming from the empirical evidence. First, the clusters 'yuppies' and 'unwilling' demonstrate the permeability between management and management consulting, and enable discussing to what extent there is (still) a boundary between the two. In traditional terms, management consultants have always been seen as ancillary figures to management in their role as agents of managerial power (Fincham, 2003) and of organizational change (Muzio et al, 2013). But the empirical evidence in the paper shows how these figures are two sides of the same coin; "wanna-be" managers go to consulting to learn the practice of management, failed managers go back to consulting when their career as managers is over. Sturdy et al (2014) remark that there is a proactive recruitment of consultants into management positions, especially if the consultant has been employed in major global firms. This implies that managerial practices are hybridizing with consultancy, but the empirical evidence shows that consultancy is hybridizing with management as well. That is, in anticipation of a management career perspective as shown by 'yuppies', or ex-post for implementation of past strategies as in 'unwilling'.

Secondly, work settings matters, but the strength of affiliation to profession does too. Two clusters ('self-employed' and 'yuppie') are characterised by weak emotional attachment to the profession. In the first case, a strong investment in consulting is considered an impediment to future change in the service offered to the market. Consequently, professionalism is a selfpromotion strategy towards potential clients and it is assumed temporarily, only as long as the return on this investment is positive. For 'yuppie', the weak consultancy affiliation does not allow going beyond a conformist and instrumental adherence to the discourse of professionalism proposed by their corporation. Hence, professionalism is a discourse imposed 
by their organisations from above and accepted for convenience, as long as it is profitable for their future career prospects as managers.

Last but not least, management consultants display peculiarities in the way they embody the organizing professionalism of the 'professional' cluster. Professionalism in this case represents the discourse closest to pure forms of professionalism within management consultants (Noordegraaf, 2007), regarding the importance accorded to expertise and commitment to profession. But, according to the literature (Noordegraaf 2007 and 2015), pure professionalism is the outcome of a process of institutionalization driven by professional association. 'Professional' management consultants refuse categorically to follow this type of professionalisation; more than the role of institutions, they rather stress the importance of expertise which is built and shared in the work setting within which they work.

Socialization is the process by which members of an occupational community acquire values, norms and worldviews that are considered important, and shared and respected within this community (Anteby et al, 2016). Professional consultants differ from 'collegial' forms of professionalism, because their socialisation to management consultancy arises through a reflexive mechanism, in which the practices are shared with peers and within work settings, thus generating multiple professional communities. This empirical evidence confirms once more the emergence of new forms of professionalism, triggered by the intersections of organizational logics with professions among 'new' management occupations (Heusinkveld et al, 2018). But it also advances knowledge in the field, as professionalism is not only mediated by corporations. Small partnerships or stable networks of collaboration can also become loci of professionalism.

In summary, the evidence presented in the study demonstrated that in the context of Italian management consultancy, there are different professionalisms, and they are contemporaneously present in the field. Of these, the 'organizing professionalism' is the purest. Discursive stances of professionalism help them achieve the legitimacy, status and trust that collegial professions have achieved through institutions (Alvesson and Johansson, 2002; Muzio et al, 2011). Each work setting, however, requires different argumentations for obtaining this outcome, a possible explanation of the association noted between work setting and type of professionalism. Work settings, however, include not only corporations, smaller organizations and stable networks of collaboration for self-employed management consultants can also constitute a source of professionalism.

\section{Conclusions}

This article has investigated the role that work settings, comprising types of organizations and employment status, play in developing different varieties of professionalism within management consultancy in Italy. Thanks to an inductive analysis of 55 interviews with management consultants in Italy, it produced a typology comprising four clusters: 'professional', 'yuppie', 'unwilling' and 'self'-employed. Each one has been considered in relation to work setting, in order to map discourses associated with the management consulting profession: organising professionalism, corporate professionalism, hybrid professionalism and, finally, commercialised professionalism. In line with previous studies (Kitay and Wright, 2007; Suddaby et al, 2009), the empirical evidence shows the presence of an association between professionalisms and the work setting in which discourses are shared and socialised. Organizing professionalism is the sole discourse which is diffuse in all work settings (see cluster "professional). Other discourses are context-dependent and more likely to be found in specific work settings (see clusters: 'yuppie', 'unwilling' and 'self'-employed). The type of 
organization and the employment status of the practitioner are relevant dimensions for mapping professionalisms in the field.

The results demonstrated that applying a discursive definition of professionalism reveals the professionalisms of Italian management consultants as plural; multiplicity and heterogeneity are confirmed to be the stylistic hallmarks of management consultancy professionalism (Kitay and Wright, 2007). For Italian consultants, multiple professionalisms are accepted as different, but equally acceptable ways of enacting consultancy. Given the heterogeneity emerging from the day-to-day practices among the interviewed consultants, one could argue that multiplicity hides multiple professions and not simple multiple discourses on professionalism. Yet, even accepting this interpretation, it is the specific work setting in which consultancy is performed that defines the prevalence of one type over another. The resulting fragmentation is a legacy of the multiplicity of work settings, rather than a consequence of weak professional commitment from practitioners. This article shows that discourses on professionalism are local and contingent, resulting from certain times, places, networks, organizations and people that comprise the work setting (Cohen et al, 2005).

Table 2 expands upon the previous literature on professionalism in management consultants, emphasising the role played by work settings in defining professional discourse. The value added by the typology outlined above is that it connects with previous debates on professionalism (Hanlon, 1998; Nooerdegraaf, 2007 and 2015; Muzio et al., 2011), reshaping and applying previously theorised concepts to interpret the empirical evidence yielded by the study. Instead of introducing new jargon, the study provides empirical support for previous theoretical analyses by demonstrating how multiple discourses might co-exist within the same professional arena (Butler and Collins, 2016). This typology of professionalisms offers several advantages for the community of scholars. Primarily, it accounts for multiplicity, and as a consequence, does not privilege any particular pattern of professionalism, showing that they can all have the same legitimacy. Secondly, it provides a connection between already theorised models of professionalism, helping to systematize recent theory on professions without adding further neologisms. Thirdly, it can be applied in future research to test the validity of its heuristic capacity as an analytical frame.

Heterogenous forms of professionalism are not the exception, but the rule when studying the 'new' management occupations. Professions are institutional agents that trigger change in organizational fields (Scott, 2008; Muzio et al, 2013). Hence, the increasing heterogeneity in professionalism might impact on the future evolution of organizations. But results of this investigation show that professionalism is a contextual and dynamically evolving phenomenon as well. Work settings, as a combination of the type of organizations and employment status, also have an impact on the type of professionalism sustained by practitioners. This circular relationship leads me to conclude that organizations and professionalisms are irreducible factors that cannot effectively be studied separately. This calls for a new understanding of their role in the professionalization of 'new' management occupations. 


\section{REFERENCES (APA $6^{\text {th }}$ Edition)}

Ackroyd, S., \& Muzio, D. (2007). The Reconstructed Professional Firm: Explaining Change in English Legal Practices. Organization Studies, 28(5), 729-747. https://doi.org/10.1177/0170840607073077

Adamson, M., Manson, S., \& Zakaria, I. (2015). Executive remuneration consultancy in the UK: exploring a professional project through the lens of institutional work. Journal of Professions and Organization, 2(1), 19-37. https://doi.org/10.1093/jpo/jou007

Alvehus, J., \& Spicer, A. (2012). Financialization as a strategy of workplace control in professional service firms. Critical Perspectives on Accounting, 23(7-8), 497-510. https://doi.org/10.1016/j.cpa.2012.02.001

Alvesson, M. (2006). The Best and the Brightest: The Construction, Significance and Effects of Elite Identities in Consulting Firms. Organization, 13(2), 195-224. https://doi.org/10.1177/1350508406061674

Alvesson, M., \& Johansson, A. (2002). Professionalism and politics in management consultancy work. In T. Clark \& R. Fincham (Eds.), Critical consulting (pp. 228-246). Oxford: Blackwell.

Anteby, M., Chan, C. K., \& DiBenigno, J. (2016). Three Lenses on Occupations and Professions in Organizations: Becoming, Doing and Relating. The Academy of Management Annals, 10(1), 183-244.

Arthur, M. B., Khapova, S. N., \& Wilderom, C. P. M. (2005). Career success in a boundaryless career world. Journal of Organizational Behavior, 26(2), 177-202. https://doi.org/10.1002/job.290

ASSOCONSULT. (2015). Osservatorio sul management consulting in Italia. Rapporto annuale 2014â "2015. Retrieved from https://goo.gl/G87KDG

Bamberg, M. (1997). Positioning between structure and performance. Journal of Narrative and Life History, 7(1-4), 335-342.

Becker, H. (1970). Sociological Work. Method and Substance. Chicago: Aldine Publishing Company.

Bichi, R. (2002). L'intervista biografica. Una proposta metodologica. Milano: Vita \& Pensiero.

Brock, D. M. (2006). The changing professional organization: A review of competing archetypes. International Journal of Management Reviews, 8(3), 157-174. https://doi.org/10.1111/j.1468-2370.2006.00126.x

Butler, N., \& Collins, D. (2016). The failure of consulting professionalism? A longitudinal analysis of the Institute of Management Consultants. Management and Organizational History, 11(1), 48-65. https://doi.org/10.1080/17449359.2016.1151363

Carollo, L., \& Solari, L. (2019). Discourses of Professionalism in Front-Line Service Work: Insights from a Case Study in an Italian Bank. Work, Employment and Society. https://doi.org/10.1177/0950017019846413

Clark, Timothy, \& Kipping, M. (2012). Researching Management Consulting: An Introduction to the Handbook. In M. Kipping \& T. Clark (Eds.), The Oxford Handbook of Management Consulting (pp. 1-33). Oxford: Oxford University press. 
Cohen, L., Wilkinson, A., Arnold, J., \& Finn, R. (2005). "Remember I'm the bloody architect!": Architects, organizations and discourses of profession. Work, Employment \& Society, 19(4), 775-796. https://doi.org/10.1177/0950017005058065

Colli, A. (2010). Dwarf giants, giant dwarfs. Reflections about the Italian 'industrial demography" at the beginning of the new millennium.' Journal of Modern Italian Studies, 15(1), 43-60. https://doi.org/10.1080/13545710903465531

Collins, D., \& Butler, N. (2019). Success and Failure in Professional Projects: The Nature, Contours and Limits of Consulting Professionalism. British Journal of Management, 00(0), 113. https://doi.org/10.1111/1467-8551.12331

Costas, J., Blagoev, B., \& Kärreman, D. (2016). The arena of the professional body: Sport, autonomy and ambition in professional service firms. Scandinavian Journal of Management, 32(1), 10-19. https://doi.org/10.1016/j.scaman.2015.10.003

Costas, J., \& Grey, C. (2014). The Temporality of Power and the Power of Temporality: Imaginary Future Selves in Professional Service Firms. Organization Studies, 35(6), 909-937. https://doi.org/10.1177/0170840613502768

Cucca R and Maestripieri L (2014) Architects and Consultants between Formal Regulation and Organised Professionalism. Cambio 4(7): 25-40.

Davies, B., \& Harré, R. (1990). Positioning: The discursive production of selves. Journal for the Theory of Social Behaviour, 20(1), 43-63.

Evetts, J. (2013). Professionalism: Value and ideology. Current Sociology, 61(5-6), 778-796. https://doi.org/10.1177/0011392113479316

Faulconbridge, J. R., \& Muzio, D. (2007). Reinserting the professional into the study of globalizing professional service firms: The case of law. Global Networks, 7(3), 249-270. https://doi.org/10.1111/j.1471-0374.2007.00168.x

Fincham, R. (2003). The Agent's Agent. Power, Knowledge, and Uncertainty in Management Consultancy. International Studies of Management \& Organization, 32(4), 67-86.

Fincham, R. (2006). Knowledge work as occupational strategy: Comparing IT and management consulting. New Technology, Work and Employment, 21(1), 16-28. https://doi.org/10.1111/j.1468-005X.2006.00160.x

Fincham, R. (2012). Expert labour as a differentiated category: Power, knowledge and organisation. New Technology, Work and Employment, 27(3), 208-223. https://doi.org/10.1111/j.1468-005X.2012.00288.x

Furusten, S. (2013). Commercialized professionalism on the field of management consulting. Journal of Organizational Change Management, 26(2), 265-285. https://doi.org/10.1108/09534811311328344

Gill, M. J. (2015). Elite identity and status anxiety: An interpretative phenomenological analysis of management consultants. Organization, 22(3), 306-325. https://doi.org/10.1177/1350508413514287

Grey, C. (1998). On being a professional in a "Big Six" firm. Accounting, Organizations and Society, 23(5-6), 569-587. https://doi.org/10.1016/S0361-3682(97)00003-2

Hanlon, G. (1998). Professionalism as Enterprise: Service Class Politics and the Redefinition of Professionalism. Sociology, 32(1), 43-63. https://doi.org/10.1177/0038038598032001004 
Heusinkveld, S., Gabbioneta, C., Werr, A., \& Sturdy, A. (2018). Professions and (new) management occupations as a contested terrain: Redefining jurisdictional claims. Journal of Professions and Organization, 5(3), 248-261. https://doi.org/10.1093/jpo/joy015

Ibarra, H., \& Barbulescu, R. (2010). Identity As Narrative: Prevalence, Effectiveness, and Consequences of Narrative Identity Work in Macro Work Role Transitions. Academy of Management Review, 35(1), 135-154.

Kieser, C., \& Groß, Alfred. (2006). Are Consultants Moving Towards Professionalization? In R. S. Royston Greenwood (Ed.), Professional Service Firms (Vol. 24, pp. 69-100). Amsterdam: Elsevier.

Kipping, M. (2011). Hollow from the start? Image professionalism in management consulting. Current Sociology, 59, 530-550. https://doi.org/10.1177/0011392111402727

Kitay, J., \& Wright, C. (2007). From prophets to profits: The occupational rhetoric of management consultants. Human Relations, 60(11), 1613-1640. https://doi.org/10.1177/0018726707084302

Kohler Riessman, C. K. (2008). Narrative methods for the human sciences. Thousdand Oaks: Sage.

Kumra, S., \& Vinnicombe, S. (2008). A study of the promotion to partner process in a professional services firm: How women are disadvantaged. British Journal of Management, 19(SUPPL. 1), S65-S74. https://doi.org/10.1111/j.1467-8551.2008.00572.x

Leicht, K. T. (2016). Market fundamentalism, cultural fragmentation, post-modern skepticism, and the future of professional work: Table 1. Journal of Professions and Organization, 3(1), 103-117. https://doi.org/10.1093/jpo/jov006

Maestripieri L (2013) Consulenti di Management. Il professionalismo organizzativo nel lavoro di conoscenza. Torino: L'Harmattan.

Maestripieri L (2016) Professionalization at work: The case of Italian management consultants. Ephemera. Theory \& politics in organization 16(2): 33-54.

Maestripieri L and Cucca R (2018) Small is beautiful? Emerging organizational strategies among Italian professionals. Canadian Review of Sociology 55(33).

Morris, T., \& Pinnington, A. (1998). Promotion to partner in professional service firms. Human Relations, 51(1), 3-24. https://doi.org/10.1177/001872679805100102

Muzio, D., Ackroyd, S., \& Chanlat, J.-F. (2007). Introduction: Lawyers, Doctors and Business Consultants. In D. Muzio, S. Ackroyd, \& J.-F. Chanlat (Eds.), Redirections in the Study of Expert Labour. Established Professions and New Expert Occupations (pp. 1-28). Berlin: Springer.

Muzio, D., Brock, D. M., \& Suddaby, R. (2013). Professions and institutional change: Towards an institutionalist sociology of the professions. Journal of Management Studies, 50(5), 699721. https://doi.org/10.1111/joms.12030

Muzio, D., Hodgson, D., Faulconbridge, J. R., Beaverstock, J., \& Hall, S. (2011). Towards corporate professionalization: The case of project management, management consultancy and $\begin{array}{lllll}\text { executive } & \text { search. } & \text { Current } & \text { Sociology, } & \text { 59(4), }\end{array}$ https://doi.org/10.1177/0011392111402587

Noordegraaf, M. (2007). From "Pure" to "Hybrid" Professionalism: Present-Day Professionalism in Ambiguous Public Domains. Administration \& Society, 39(6), 761-785. https://doi.org/10.1177/0095399707304434 
Noordegraaf, M. (2015). Hybrid professionalism and beyond: (New) Forms of public professionalism in changing organizational and societal contexts. Journal of Professions and Organization, 2(2), 187-206. https://doi.org/10.1093/jpo/jov002

Noordegraaf, M., Van Der Steen, M., \& Van Twist, M. (2014). Fragmented or connective professionalism? Strategies for professionalizing the work of strategists and other (organizational) professionals. Public Administration, 92(1), 21-38. https://doi.org/10.1111/padm.12018

Olagnero, M., \& Saraceno, C. (1993). Che vita è. L'uso dei materiali biografici nell'analisi sociologica. Roma: Nuova Italia Scientifica.

Olakivi, A., \& Niska, M. (2016). Rethinking managerialism in professional work: From competing logics to overlapping discourses: Journal of Professions and Organization, (August 2016), jow007. https://doi.org/10.1093/jpo/jow007

Ranci, C. (2012). Partite Iva. Il lavoro autonomo nella crisi italiana. Bologna: Il Mulino editore.

Reed, M. I. (1996). Expert Power and Control in Late Modernity: An Empirical Review and Theoretical Synthesis. Organization Studies, 17(4), 573-597. https://doi.org/10.1177/017084069601700402

Rivera, L. A. (2012). Hiring as Cultural Matching: The Case of Elite Professional Service Firms. American Sociological Review, 77(6), 999-1022. https://doi.org/10.1177/0003122412463213

Rodrigues, R., Guest, D., \& Budjanovcanin, A. (2013). From anchors to orientations: Towards a contemporary theory of career preferences. Journal of Vocational Behavior, 83(2), 142-152. https://doi.org/10.1016/j.jvb.2013.04.002

Scott, W. R. (2008). Lords of the Dance: Professionals as Institutional Agents. Organization Studies, 29(2), 219-238. https://doi.org/10.1177/0170840607088151

Stenger, S. (2017). Au cor des cabinets d'audit et de conseil. De la distinction à la soumision. Paris: PUF.

Sturdy, A. (2011). Consultancy's consequences? A critical assessment of management consultancy's impact on management. British Journal of Management, 22(3), 517-530. https://doi.org/10.1111/j.1467-8551.2011.00750.x

Sturdy, A., Wright, C., \& Wylie, N. (2014). Managers as consultants: The hybridity and tensions of neo-bureaucratic management. Organization, 23(2), 184-205. https://doi.org/10.1177/1350508414541580

Suddaby, R., Gendron, Y., \& Lam, H. (2009). The organizational context of professionalism in accounting. Accounting, Organizations and Society, 34(3-4), 409-427. https://doi.org/10.1016/j.aos.2009.01.007

Vinkenburg, C. J., \& Weber, T. (2012). Managerial career patterns: A review of the empirical evidence. Journal of Vocational Behavior, 80(3), 592-607. https://doi.org/10.1016/j.jvb.2012.02.001

Watson, T. (2002). Professions and Professionalismâ "Should we jump off the bandwagon, Better to Study where it is going? International Studies of Management \& Organization, 32(2), 93-105.

Ybema, S. (2004). Managerial postalgia: Projecting a golden future. Journal of Managerial Psychology, 19(8), 825-841. https://doi.org/10.1108/02683940410568284 